\title{
Analisis Pola Penggunaan Remitansi Serta Dampaknya Terhadap Perkembangan Daerah Asal: Studi Kasus Pada Desa Widarapayung Wetan, Kecamatan Binangun, Kabupaten Cilacap, Provinsi Jawa Tengah
}

\author{
Fitra Khoirunnisa ${ }^{1}$ dan Ahmad Maruf ${ }^{1}$
}

\begin{abstract}
Abstrak: Penelitian ini bertujuan untuk menganalisis pola penggunaan remitansi serta dampaknya terhadap perkembangan daerah asal. Penelitian ini merupakan penelitian deskriptif kuantitatif dan kualitatif. Jenis data yang digunakan dalam penelitian ini adalah data primer yang berupa hasil kuisioner dan hasil wawancara yang dilakukan pada TKI di Desa Widarapayung Wetan, Kecamatan Binangun,

Kabupaten Cilacap, Provinsi Jawa Tengah untuk menguji hipotesis penelitian. Data sekunder yang digunkan dalam penelitian ini berasal dari instansi-instansi terkait untuk mendukung kelengkapan data dalam penelitian ini. Variabel yang digunakan dalam penelitian ini terdiri dari variabel bebas yaitu, konsumsi, investasi, sosial, dan tabungan, serta varibel terikat yaitu dampak terhadap perkembangan daerah asal. Metode analisis data dalam penelitian ini menggunakan metode analisis regresi linier berganda. Berdasarkan hasil penelitian, diperoleh hasil bahwa variabel konsumsi, investasi, sosial dan tabungan berpengaruh positif dan signifikan terhadap perkembangan daerah asal.

Kata kunci: Remitansi; TKI; Konsumsi; Investasi; Tabungan.
\end{abstract}

AFILIASI:

${ }^{1}$ Department of Economics, Faculty of Economics and Business, Universitas Muhammadiyah Yogyakarta, Yogyakarta, Indonesia.

*KORESPONDENSI:

fitra.khoirunnisa.2015@fe.umy.ac.id

THIS ARTICLE IS AVALILABLE IN:

http://journal.umy.ac.id/index.php/jerss

DOI: 10.18196/jerss.030105

SITASI:

Khoirunnisa, F., \& Maruf, A. (2019). Analisis Pola Penggunaan Remitansi Serta Dampaknya Terhadap Perkembangan Daerah Asal: Studi Kasus Pada Desa Widarapayung Wetan, Kecamatan Binangun, Kabupaten Cilacap, Provinsi Jawa Tengah. Journal of Economics Research and Social Sciences, 3(1), 38-47.

\section{Pendahuluan}

Perbedaan antara negara berkembang dengan negara maju menjadi salah satu faktor utama penarik migrasi internasional, di mana permasalahan migrasi diawali dengan terjadinya ketimpangan pembangunan di negara berkembang yang mengakibatkan tingginya tingkat pengangguran. Hal utama yang menyebabkan tingkat pengangguran tinggi adalah minimnya tingkat pendidikan yang dimiliki oleh masyarakat di negara berkembang. Kondisi sumber daya manusia di negara maju dan negara berkembang sangatlah berbeda. Negara berkembang dihadapkan kepada suatu realitas bahwa produktivitas tenaga kerjanya cenderung rendah akibat dari rendahnya kualitas sumber daya manusia (Mustapita \& Rizal, 2017). Akibat dari rendahnya keahlian yang dimiliki dan lapangan pekerjaan yang cenderung mencari tenaga ahli di bidangnya, maka menyebabkan terjadinya ketimpangan antara pencari pekerjaan dan lapangan pekerjaan. Ketimpangan tersebut yang akhirnya menjadi alasan para migran untuk mencari pekerjaan ke negara lain yang dianggap dapat memberikan keuntungan tinggi. 
Selain itu, masalah lainnya yang mungkin akan terjadi, misalnya seperti terhambatnya suatu desa untuk mengalami perubahan atau kemajuan, padahal desa tersebut memiliki potensi yang cukup bagus untuk dikembangkan. Akibat dari langkanya tenaga kerja yang mampu mengelola potensi daerah tersebut, menyebabkan sumber daya yang tersedia hanya dibiarkan sia-sia tanpa dimanfaatkan. Tetapi sebagian besar masyarakat masih beranggapan bahwa melakukan migrasi itu wajar dan merupakan hal yang positif.

Dampak dari adanya migrasi internasional yaitu pengiriman remitansi yang diperkirakan mampu memberikan kontribusi terhadap perkembangan daerah asal. Dimana perkembangan daerah asal bisa dilihat dari beberapa indikator seperti naiknya fasilitas desa akibat dari tingginya tingkat sumbangan yang diberikan oleh migran untuk memperbaiki fasilitas. Fasilitas tersebut dapat berupa perbaikan jalan, pembangunan SD atau TK, pembangunan masjid, pembangunan posyandu dan lain sebagainya. Dampak lain yang akan terjadi yaitu naiknya tingkat konsumsi dan pengeluaran individu, serta kemampuan untuk menabung juga akan tinggi karena pendapatan yang diperoleh tinggi. Menurut data dari Badan Nasional Penempatan dan Perlindungan Tenaga Kerja Indonesia (BNP2TKI), di Provinsi Jawa Tengah, Kabupaten Cilacap menempati posisi pertama dalam pengiriman jumlah Tenaga Kerja Indonesia (TKI) terbanyak dalam kurun waktu 2012-2017. Berdasarkan data dari Badan Nasional Penempatan dan Perlindungan Tenaga Kerja Indonesia (BNP2TKI) dan Pos Pelayanan Penempatan dan Perlindungan Tenaga Kerja Indonesia (P4TKI) Cilacap, pada tahun 2017 jumlah remitansi atau kiriman yang dikirim para migran ke negara asal mereka kurang lebih sejumlah Rp 500 miliar per tahun.

Penelitian mengenai pemanfaatan remitansi juga telah dilakukan oleh Putra, dkk (2012) dan hasil penelitiannya menyebutkan bahwa remitansi yang diperoleh lebih dimanfaatkan untuk kepentingan yang bersifat produktif. Seperti membuka usaha, membiayai pendidikan anak, merenovasi rumah, membeli tanah, dan ditabung. Berdasarkan uraian latar belakang di atas, peneliti tertarik untuk melakukan penelitian mengenai pola penggunaan remitansi serta dampaknya terhadap perkembangan daerah asal.

\section{Tinjauan Pustaka}

Penelitian lain yang dilakukan oleh Mustapita dan Rizal (2017) tentang analisis pola penggunaan remitansi menyatakan bahwa penggunaan remitansi lebih banyak digunakan pada pola penggunaan konsumtif dibanding dengan pola penggunaan produktif. Pola konsumtif yang digunakan para migran di Kabupaten Malang antara lain meliputi renovasi rumah, pemenuhan kebutuhan sehari-hari, pembelian barang elektronik, pembelian kendaraan, dan juga digunakan untuk pembayaran hutang.

Menurut Irnawati (2015), penggunaan remitansi internal di desa Krambilsawit sebagian besar digunakan untuk memenuhi kebutuhan rumah tangga, dan sisanya digunakan untuk menabung (saving) dan investasi. Fakta lain menunjukkan bahwa telah terjadi 


\begin{abstract}
Khoirunnisa \& Maruf
Analisis Pola Penggunaan Remitansi Serta Dampaknya Terhadap Perkembangan Daerah Asal: ...
\end{abstract}

perubahan remitansi yang dibawa oleh migran ke desa asal, yang awalnya digunakan untuk pemenuhan kebutuhan konsumsi, beralih menjadi bentuk investasi sosial yang berimbas pada perubahan status dan struktur sosial masyarakat yang ditandai dengan adanya kelas sosial juragan di desa tersebut. Selain itu remitansi juga berdampak pada pembangunan ekonomi desa dengan munculnya berbagai macam usaha mandiri milik warga. Menurut Wafirotin, (2013) dampak yang terjadi ketika seseorang melakukan migrasi diantaranya adalah peningkatan pengetahuan dan pendidikan anggota keluarga migran, peningkatan pendapatan serta peningkatan status kepemilikan barang berharga yang dimiliki oleh keluarga migran.

Pola penggunaan remitansi ekonomi merupakan pola tertinggi yang digunakan di Desa Mojolawaran dan Desa Jimbaran. Penggunaan remitansi ekonomi di dua desa tersebut digunakan untuk perbaikan rumah dan pembelian tanah guna investasi yang akan memberikan nilai tambah dalam jangka panjang. Dampak dalam penggunaan remitansi ekonomi yang terjadi di Desa Mojolawaran dan Desa Jimbaran antara lain yaitu peningkatan jumlah pendapatan, dan peningkatan pendidikan. Dampak remitansi sosial di Desa Mojolawaran dan Desa Jimbaran yaitu adanya peningkatan status sosial, yang ditandai dengan keikutsertaan migran dalam politik desa ketika mereka kembali ke daerah asalnya (Diyantoro \& Alie, 2014).

Dalam penelitian yang dilakukan oleh Justino dan Shemyakina (2012), mengatakan bahwa remitansi dapat mempengaruhi keputusan bekerja anggota rumah tangga migran di Tajkistan. Dimana remitansi memiliki pengaruh negatif terhadap partisipasi angkatan kerja laki-laki dan perempuan. Artinya, jika semakin besar remitansi yang dikiriman ke rumah tangga migran di daerah asal, anggota keluarga cenderung enggan untuk bekerja. Lueth dan Ruiz-Arranz (2006) menyatakan bahwa adanya pengaruh negatif terhadap bisnis rumahan di sebuah negara. Artinya dana remitansi tidak mendorong terjadinya bisnis rumahan, untuk mendorong tingkat remitansi dan memaksimalkan dampaknya terhadap perekonomian maka perlu adanya pengurangan kebijakan biaya transaksi, pembangunan terhadap sektor keuangan harus dan juga iklim bisnis perlu lebih ditingkatkan kembali.

Migran yang tidak memiliki ketrampilan cenderung mendapatkan remitansi dengan tingkat yang lebih sedikit dibanding dengan migran yang memiliki ketrampilan (Petrova, 2015). Sedangkan penelitian yang dilakukan oleh Ranathunga (2011), menyatakan bahwa di Sri Lanka remitansi memiliki pengaruh positif terhadap pendapatan bulanan migran dan memiliki pengaruh negatif terhadap pendapatan rumah tangga pertanian, baik secara bulanan maupun tahunan. Menurut Sulistyorini, Oktaviani, and Hutagol (2014) remitansi berkontribusi pada peningkatan rumah tangga pendapatan khususnya rumah tangga buruh tani. Selanjutnya, penerimaan uang kiriman dari migran mampu mengurangi ketimpangan pendapatan di Indonesia. Penelitian yang dilakukan oleh Noveria (2010), menyatakan bahwa dampak migrasi TKI terhadap daerah asal tidak hanya memberikan manfaat bagi migran dan keluarganya, akan tetapi juga bagi daerah asal. Manfaat tersebut dirasakan mulai dari tingkat desa, kecamatan sampai tingkat kabupaten. Hasil kiriman yang diberikan oleh TKI pada keluarga asal digunakan untuk 
memenuhi berbagai kebutuhan, yang paling utama adalah untuk memenuhi kebutuhan sehari-hari seperti konsumsi, dan biaya pendidikan anak-anak.

\section{Metode Penelitian}

Dalam penelitian ini objek penelitian yang digunakan adalah Desa Widarapayung Wetan, Kecamatan Binangun, Kabupaten Cilacap, Provinsi Jawa Tengah yang warganya melakukan migrasi ke Negara Korea Selatan. Data yang digunakan dalam penelitian ini adalah data primer. Data primer adalah data yang mengacu pada informasi yang diperoleh langsung oleh peneliti yang berkaitan dengan variabel minat untuk tujuan studi yang spesifik (Sekaran, \& Bougie, 2013). Data primer yang diperoleh dari penelitian ini berasal dari jawaban responden yang telah mengisi kuisioner dan hasil wawancara, dimana data tersebut yang nantinya akan dijadikan input untuk proses analisis dan pengujian hipotesis.

Selain menggunakan data primer, penelitian ini juga menggunakan data sekunder sebagai acuan dalam penelitian. Data sekunder yang digunakan dalam penelitian ini diperoleh dari studi literatur jurnal, tesis, yang memiliki tema sama serta instansi yang memiliki kaitan dengan penelitian ini. Sumber data yang diperoleh untuk penelitian ini berasal dari hasil pengisian kuisioner dan wawancara terhadap responden yang nantinya akan diolah menggunakan analisis pengolah data SPSS v 20 dan Ms. Exel 2010.

Dalam penelitian ini penulis menggunakan teknik pengambilan sampel dengan menggunakan total sampling. Total sampling adalah pengambilan sampel yang sama dengan jumlah populasi (Arikunto, 2006). Banyaknya jumlah sampel diperoleh dari informasi yang disampaikan oleh pengelola LPK Master Korea, bahwa jumlah migran yang bermigrasi ke negara Korea Selatan dari Desa Widarapayung Wetan kurang lebih sebanyak 130 orang. Dalam penelitian ini akan mengambil secara keseluruhan total responden tersebut, yaitu sebanyak 130 orang

\section{Hasil dan Pembahasan}

Hasil pengujian validitas dengan menggunakan perangkat lunak SPSS 20 for Windows dapat dilihat pada Tabel 1.

Hasil uji validitas pada Tabel 1 menunjukkan bahwa seluruh pernyataan pada variabel konsumsi (X1), variabel investasi (X2), sosial (X3), tabungan (X4), dan perkembangan daerah asal $(Y)$ memiliki nilai $r$ hitung lebih besar dari $r$ tabel $=0,195$, maka seluruh butir pernyataan pada masing-masing variabel penelitian seperti yang tercantum dalam kuesioner dinyatakan valid. 
Khoirunnisa \& Maruf

Analisis Pola Penggunaan Remitansi Serta Dampaknya Terhadap Perkembangan Daerah Asal: ...

Tabel 1 Hasil Uji Validitas

\begin{tabular}{|c|c|c|c|c|}
\hline Variabel & Item & $r$ hitung & $r$ tabel & Keterangan \\
\hline \multirow[t]{8}{*}{ Konsumsi (X1) } & K1 & 0,486 & 0,195 & Valid \\
\hline & $\mathrm{K} 2$ & 0,644 & 0,195 & Valid \\
\hline & K3 & 0,822 & 0,195 & Valid \\
\hline & K4 & 0,585 & 0,195 & Valid \\
\hline & K5 & 0,832 & 0,195 & Valid \\
\hline & K6 & 0,245 & 0,195 & Valid \\
\hline & K7 & 0,305 & 0,195 & Valid \\
\hline & K8 & 0,566 & 0,195 & Valid \\
\hline \multirow[t]{5}{*}{ Investasi (X2) } & 11 & 0,492 & 0,195 & Valid \\
\hline & 12 & 0,453 & 0,195 & Valid \\
\hline & 13 & 0,333 & 0,195 & Valid \\
\hline & 14 & 0,319 & 0,195 & Valid \\
\hline & 15 & 0,756 & 0,195 & Valid \\
\hline \multirow[t]{9}{*}{ Sosial (X3) } & S1 & 0,702 & 0,195 & Valid \\
\hline & S2 & 0,793 & 0,195 & Valid \\
\hline & S3 & 0,767 & 0,195 & Valid \\
\hline & S4 & 0,826 & 0,195 & Valid \\
\hline & S5 & 0,809 & 0,195 & Valid \\
\hline & S6 & 0,464 & 0,195 & Valid \\
\hline & S7 & 0,539 & 0,195 & Valid \\
\hline & S8 & 0,522 & 0,195 & Valid \\
\hline & S9 & 0,465 & 0,195 & Valid \\
\hline \multirow[t]{8}{*}{ Tabungan (X4) } & $\mathrm{T} 1$ & 0,594 & 0,195 & Valid \\
\hline & $\mathrm{T} 2$ & 0,501 & 0,195 & Valid \\
\hline & T3 & 0,863 & 0,195 & Valid \\
\hline & $\mathrm{T} 4$ & 0,743 & 0,195 & Valid \\
\hline & T5 & 0,784 & 0,195 & Valid \\
\hline & T6 & 0,855 & 0,195 & Valid \\
\hline & $\mathrm{T7}$ & 0,564 & 0,195 & Valid \\
\hline & T8 & 0,369 & 0,195 & Valid \\
\hline \multirow{5}{*}{$\begin{array}{l}\text { Perkembangan } \\
\text { Daerah Asal (Y) }\end{array}$} & PD1 & 0,397 & 0,195 & Valid \\
\hline & PD2 & 0,501 & 0,195 & Valid \\
\hline & PD3 & 0,753 & 0,195 & Valid \\
\hline & PD4 & 0,794 & 0,195 & Valid \\
\hline & PD5 & 0,764 & 0,195 & Valid \\
\hline
\end{tabular}

Sumber: Hasil Olah Data Spss, 2019

Tabel 2 Hasil Uji Reliabilitas

\begin{tabular}{|c|c|c|}
\hline Variabel & Cronbach's Alpha & Keterangan \\
\hline Konsumsi (X1) & 0.721 & Reliabel \\
\hline Investasi (X2) & 0,645 & Reliabel \\
\hline Sosial (X3) & 0,839 & Reliabel \\
\hline Tabungan (X4) & 0,798 & Reliabel \\
\hline Perkembangan daerah asal (Y) & 0,655 & Reliabel \\
\hline
\end{tabular}

Sumber: Hasil Olah Data Spss, 2019 
Analisis Pola Penggunaan Remitansi Serta Dampaknya Terhadap Perkembangan Daerah Asal: ...

Hasil uji reliabilitas pada Tabel 2 menunjukkan bahwa nilai Cronbach's Alpha dari seluruh variabel penelitian lebih besar dari 0,60, maka dapat disimpulkan bahwa semua butirbutir pernyataan yang ada pada variabel dinyatakan reliabel atau dapat diandalkan.

Dalam penelitian ini, hasil uji asumsi klasik dapat dilihat pada tabel 3:

Tabel 3 Uji Asumsi Klasik

\begin{tabular}{llcccc}
\hline \multicolumn{1}{c}{ Variabel } & \multicolumn{2}{c}{ Multikolinieritas } & Heteroskedastisitas & Normalitas \\
& & VIF & & Sig. & $\begin{array}{c}\text { Asymp. Sig. } \\
\text { (2-tailed) }\end{array}$ \\
\hline Konsumsi & 0,943 & 1,061 & 0,406 & & 0,132 \\
Investasi & 0,950 & 1,052 & 0,081 & \\
Sosial & 0,944 & 1,059 & 0,736 & \\
Tabungan & 0,964 & 1,038 & 0,794 & & \\
\hline
\end{tabular}

Sumber: Data primer diolah, 2019

Berdasarkan hasil uji asumsi klasik yang ditunjukkan pada tabel 3, diketahui bahwa seluruh data yang digunakan pada penelitian ini lolos uji asumsi klasik.

Tabel 4 Hasil Analisis Regresi Berganda

\begin{tabular}{|c|c|c|c|c|}
\hline Variabel Bebas & $\begin{array}{c}\text { Koefisien } \\
\text { Regresi } \\
(\beta)\end{array}$ & t-hitung & Sig. & Kesimpulan \\
\hline Konsumsi (X1) & 0,138 & 2,904 & 0,005 & Sig \\
\hline Investasi (X2) & 0,157 & 2,086 & 0,040 & Sig \\
\hline Sosial (X3) & 0,168 & 6,361 & 0,000 & Sig \\
\hline Tabungan (X4) & 0,244 & 7,558 & 0,000 & Sig \\
\hline \multicolumn{5}{|c|}{ Konstanta $(a)=-1,063$} \\
\hline \multicolumn{5}{|c|}{ Adjusted $R^{2}=0,843$} \\
\hline \multicolumn{5}{|c|}{$F$ hitung $=139,218$} \\
\hline Sig. $F=0,000$ & & & & \\
\hline
\end{tabular}

Sumber: Hasil Olah Data Spss, 2019

Dari hasil uji regresi linier berganda yang disajikan dalam tabel 4, dapat diketahui bahwa nilai koefisien regresi masing-masing variabel bernilai positif dan taraf signifikansi lebih kecil dari 0,05. Maka dapat disimpulkan bahwa setiap variabel bebas memiliki pengaruh yang positif dan signifikan terhadap variabel terikat.

Tabel 5 Hasil Uji Hipotesis Secara Parsial

\begin{tabular}{lccccc}
\hline \multicolumn{1}{c}{ Model } & \multicolumn{2}{c}{ Unstandardized Coefficients } & $\begin{array}{c}\text { Standardized } \\
\text { Coefficients } \\
\text { Beta }\end{array}$ & T & Sig. \\
\hline (Constant) & B & Std. Error &, 699 & $-1,522$ &, $\mathbf{1 3 1}$ \\
Konsumsi (X1) & $-1,063$ &, 048 &, 212 & 2,904 &, 005 \\
Investasi (X2) &, 138 &, 075 &, 143 & 2,086 &, 040 \\
Sosial (X3) &, 157 &, 026 &, 327 & 6,361 &, 000 \\
Tabungan (X4) &, 244 &, 032 &, 410 & 7,558 &, 000 \\
\hline
\end{tabular}

Sumber: Hasil Olah Data Spss, 2019 
Berdasarkan hasil olah data pada tabel 5 dapat dilihat bahwa nilai signifikansi memiliki nilai $<0,05$. Artinya bahwa dalam penelitian ini variabel bebas memiliki pengaruh positif secara parsial terhadap variabel terikat.

Tabel 6 Hasil Uji Hipotesis secara Simultan

\begin{tabular}{lllllll}
\hline Model & Sum of Squares & df & Mean Square & F & Sig. \\
\hline $\mathbf{1}$ & Regression & 456,718 & 4 & 114,180 & 139,218 & $\mathbf{0 0 0}^{\mathbf{b}}$ \\
$\begin{array}{l}\text { Residual } \\
\quad \text { Total }\end{array}$ & $\mathbf{8 1 , 1 9 5}$ & 99 &, 820 & & \\
\hline
\end{tabular}

Sumber: Hasil Olah Data Spss, 2019

Berdasarkan hasil olah data pada tabel 6 dapat dilihat bahwa nilai signifikansi memiliki nilai $<0,05$. Artinya bahwa dalam penelitian ini variabel bebas memiliki pengaruh positif secara simultan terhadap variabel terikat.

Tabel 7 Hasil Uji R-square

\begin{tabular}{lll}
\hline$R$ & $R$ Square & Adj $R$-Square \\
\hline 0,921 & 0,849 & 0,843 \\
\hline
\end{tabular}

Sumber: Hasil Olah Data Spss, 2019

Dari hasil uji koefisien determinasi, diperoleh nilai sebesar 0,843 . Hal ini menunjukkan bahwa perkembangan daerah asal dipengaruhi oleh variabel pola penggunaan remitansi yang meliputi konsumsi, investasi, sosial, dan tabungan sebesar $84,3 \%$, sedangkan sisanya $15,7 \%$ dipengaruhi oleh faktor lain yang tidak termasuk dalam penelitian ini.

Hasil uji regresi berganda yang telah dilakukan menunjukkan adanya pengaruh positif dan signifikan dari konsumsi terhadap perkembangan daerah asal. Hal ini diperoleh dari hasil uji-t dengan nilai t-hitung sebesar 2,904 dengan nilai signifikansi sebesar 0,005 lebih kecil dari 0,01, dan koefisien regresi mempunyai nilai positif sebesar 0,138. Sehingga, hal tersebut menandakan bahwa semakin tinggi penggunaan remitansi untuk konsumsi di daerah asal responden, maka perkembangan daerah asal responden juga akan semakin tinggi. Konsumsi yang digunakan untuk renovasi rumah, pemenuhan kebutuhan pokok, biaya kesehatan, biaya pendidikan, dan asuransi dianggap penting bagi TKI desa Widarapayung Wetan. Dengan meningkatnya kesehatan dan kualitas pendidikan keluarga TKI, maka akan meningkatkan kualitas kesejahteraan keluarga.

Terdapat pengaruh positif dan signifikan dari investasi terhadap perkembangan daerah asal. Hal ini diperoleh dari hasil Uji-t dengan nilai t-hitung sebesar 2,086 dengan nilai signifikansi sebesar 0,040 $<0,05$, dan koefisien regresi mempunyai nilai positif sebesar 0,157. Dapat diartikan bahwa semakin tinggi penggunaan remitansi untuk investasi di daerah asal responden, cenderung menyebabkan semakin tinggi pula perkembangan daerah asal responden. Investasi yang dilakukan oleh warga Desa Widarapayung Wetan adalah bentuk investasi tanah atau sawah, yang dianggap mampu memberikan penghasilan dalam jangka panjang. Dengan adanya investasi tersebut juga mampu menciptakan lapangan pekerjaan. Lapangan pekerjaan ini tercipta dari adanya 
permintaan tenaga kerja untuk mengelola sawah tersebut, karena pemilik usaha tidak mampu mengelola sendiri.

Hasil uji regresi berganda yang telah dilakukan menunjukkan adanya pengaruh positif dan signifikan dari sosial terhadap perkembangan daerah asal. Hal ini diperoleh dari hasil Uji-t dengan nilai t-hitung sebesar 6,361 dengan nilai signifikansi sebesar 0,000 < 0.01 . nilai koefisien regresi variabel ini sebesar 0,168 , maka semakin tinggi penggunaan remitansi untuk kegiatan sosial, cenderung menyebabkan perkembangan daerah asal responden semakin tinggi juga. Tenaga Kerja Indonesia dari Desa Widarapayung Wetan setiap tahunnya mengumpulkan iuran yang digunakan untuk sumbangan sosial kepada daerah asal. Kontribusi sosial dari dana remitansi yang digunakan untuk sumbangan, terutama dalam meningkatkan pembangunan infrastruktur desa seperti perbaikan jalan, santunan kaum dhuafa dan anak yatim, dan pembangunan masjid.

Hasil uji regresi berganda yang telah dilakukan menunjukkan adanya pengaruh positif dan signifikan dari tabungan terhadap perkembangan daerah asal. Hal ini diperoleh dari hasil Uji-t dengan nilai t-hitung sebesar 7,558 dengan nilai signifikansi sebesar 0,000 < 0.01 , dan koefisien regresi mempunyai nilai sebesar 0,244 , maka semakin tinggi penggunaan remitansi untuk ditabung oleh responden di daerah asalnya, maka cenderung berdampak pada semakin tingginya perkembangan daerah asal responden. Pemanfaatan usaha yang didirikan di daerah asal bertujuan untuk mempertahankan tabungan. Ketika TKI sudah kembali ke daerah asal, dikhawatirkan tidak lagi memiliki penghasilan seperti ketika menjadi TKI. Pembukaan usaha seperti toko dan usaha kuliner menjadi pilihan untuk mempertahankan pendapatan dan tabungan, sehingga mereka memiliki sumber pendapatan didaerah asal dan tidak perlu kembali lagi ke negara orang. Hasil uji secara simultan yang terdapat dalam analisis regresi berganda bertujuan untuk mengetahui pengaruh semua variabel bebas meliputi konsumsi, investasi, sosial, dan tabungan secara bersama-sama terhadap perkembangan daerah asal. Apabila nilai signifikansi lebih kecil dari 0,05, maka semua variabel bebas meliputi konsumsi, investasi, sosial, dan tabungan secara bersama-sama berpengaruh signifikan terhadap perkembangan daerah asal. Hasil uji-f dalam penelitian ini seperti terlihat pada Tabel 1.6 menunjukkan nilai f-hitung sebesar 139,218 dengan signifikansi sebesar 0,000 $<0.01$. Maka dapat disimpulkan bahwa pola penggunaan remitansi yang terdiri dari konsumsi, investasi, sosial dan tabungan secara simultan berpengaruh signifikan terhadap perkembangan daerah asal.

Hasil penelitian ini sesuai dengan hasil penelitian sebelumnya dari Sagala, Pratama, Argo, dan Asirin (2012) yang menyebutkan bahwa alokasi penggunaan remitansi pada kepentingan konsumsi, tabungan, pembangunan fisik, dan investasi modal usaha bernilai positif. Dan penggunaan paling besar terdapat pada investasi modal usaha yang juga memberikan dampak positif bagi daerah asal. 


\section{Kesimpulan}

Dari serangkaian pengujian yang telah dilakukan, peneliti dapat menyimpulkan bahwa konsumsi, Investasi, sosial, serta tabungan berpengaruh positif dan signifikan terhadap perkembangan daerah asal. Artinya bahwa semakin tinggi penggunakan remitansi terhadap beberapa hal tersebut, maka akan berdampak juga pada peningkatan perkembangan daerah asal. Dampak terhadap perkembangan daerah asal yang diberikan dari pola penggunaan remitansi tersebut adalah positif. Dilihat dari setiap variabel, memiliki kontribusi yang positif terhadap perkembangan daerah asal. Terutama pada segi infrastruktur desa dan fasilitas desa. Selain itu, tidak hanya terhadap perkembangan daerah asal saja dampak yang diberikan. Melainkan juga dampak terhadap kemandirian SDM, yang digambarkan dengan kemampuan mereka dalam mengelola dana remitansi

\section{Daftar Pustaka}

Arikunto, S. (2006). Prosedur Penelitian Suatu Pendekatan Praktik. Jakarta: Rineka Cipta. Diyantoro, B., dan Alie, M. M. (2014). Pola Penggunaan Remitansi Tenaga Kerja Indonesia (TKI) Serta Pengaruhnya Terhadap Perkembangan Daerah Asal. Jurnal Teknik PWK, 3(2), 319-332. Diakses dari https://ejournal3.undip.ac.id/index.php/pwk/article/view/5072

Irnawati, N. (2015). Remitansi di Kalangan Migran Sirkuler Asal Gunungkidul (Studi Kasus Lima Rumah Tangga Migran Sirkuler Penjual Bakwan Kawi dan Bakso di Desa Krambilsawit, Kecamatan Saptosari). Thesis, Universitas Gadjah Mada.

Justino, P., Shemyakina, O. N. (2012). Remittances and labor supply in post-conflict Tajikistan. IZA J Labor Develop 1(8). https://doi.org/10.1186/2193-9020-1-8

Lueth, E., \& Ruiz-Arranz, M. (2008). Determinants of bilateral remittance flows. The BE Journal of Macroeconomics, 8(1). https://doi.org/10.2202/1935-1690.1568

Mustapita, A. F., \& Rizal M., (2017). Analisis Pola Penggunaan Remitansi Migrasi Internasional Secara Produktif dan Konsumtif di Kabupaten Malang. JU-ke (Jurnal Ketahanan Pangan), 1(2), 6-10. Diakses dari https://www.neliti.com/id/publications/269657/analisis-pola-penggunaan-remitanmigrasi-internasional-secara-produktif-dan-kons\#cite

Noveria, M. (2010). Migrasi Berulang Tenaga Kerja Migran Internasional: Kasus Pekerja Migran Asal Desa Sukorejo Wetan, Kabupaten Tulungagung. Jurnal Kependudukan indonesia, 12(1), 25-38.https://doi.org/10.14203/jki.v12i1.255

Petrova, P. (2015). Remittances, Gender and Skills: Evidence from Europe and Central Asia Region. Digitala Vetenskapliga Arkivet, Jönköping International Business School. Diakses dari https://www.divaportal.org $/ \mathrm{smash} / \mathrm{record}$.jsf? pid $=$ diva $2 \% 3$ A814949\&dswid $=5308$

Sagala, S., Pratama, A., Argo, T., \& Asirin, A. (2016). Peran Remitan Tenaga Kerja Indonesia Terhadap Potensi Pengurangan Risiko Bencana Banjir di Wilayah Perkotaan Indramayu. Tataloka, 14(1), 37-51. https://Doi.Org/10.14710/Tataloka.14.1.37-51

Sekaran, U., \& Bougie, R. (2013) Research Methods for Business: A Skill-Building Approach. 6th Edition, Wiley, New York. 
Analisis Pola Penggunaan Remitansi Serta Dampaknya Terhadap Perkembangan Daerah Asal: ...

Sulistyorini, Y., Oktaviani, R., \& Hutagol, M. P. (2014). Dampak Kebijakan Migrasi Terhadap Distribusi Pendapatan di Indonesia (Impact of Migration Policy on Income Distribution in Indonesia). Jurnal Fakultas Ekonomi Institut Pertanian Bogor, 18(1), 1-20. https://doi.org/10.26593/be.v18i1.821.\%25p

Wafirotin, K. Z. (2013). Dampak Migrasi terhadap Kondisi Sosial Ekonomi Keluarga TKI di Kecamatan Babadan, Kabupaten Ponorogo. Jurnal Ekuilibrium, 11(2), 15-33.

http://dx.doi.org/10.24269/ekuilibrium.v8i1.36 